\author{
Askar Mambetaliev \\ University of Pannonia, Hungary
}

\title{
BARRIERS TO AND STRATEGIES FOR SUSTAINABLE RELATIONSHIPS IN MULTILINGUAL CAMPUSES
}

Summary. The article presents the dimensions of communication in multiethnic and multilingual education settings, the main barriers to sustainable relationships between students of different backgrounds and strategies to overcome those barriers. The main research question of the study is: What are the main barriers in sustainable relationships between students with different ethnic and linguistic backgrounds? A subsequent question is: How to overcome those barriers? Hence, the main goal of the article is to identify and address the main problems that undermine mutual understanding and collaborative learning among students. The method of the study is a literature review of the most significant studies and authors in the field. The goal is to present an analysis of their insights into the main problems of relationships between students on international campuses. The article is useful for campus leaders, students and mentors.

Keywords: communication; relationships; multilingual; barriers; racism; prejudice; stereotypes; strategies.

\section{Introduction}

\section{The main dimensions of communication in multilingual campuses}

Effective communication in multiethnic and multilingual education settings requires at least a capability to communicate in the languages of students, and to interpret the cultural associations of the nonverbal information. In many cases, discrimination based on language may present serious problems for minorities, because "a language is not just a component of the culture but is also the major means of expressing the culture" (Matthew, 1994, p. 61). A recent study of pluralism in Kyrgyzstan, for example, lists the discrimination that is based on language as one of the main problems in relationships between ethnic Russians and the Kyrgyz (Mambetaliev, 2018).

Furthermore, for lasting relationships in multilingual education settings, not only language, but also intercultural communication is important as well. The lack of skills in either part of the pair may contribute to a failure of communication between individuals from different linguistic and cultural 
backgrounds. One should be aware of the cultural dimension of language in order to avoid becoming a "fluent fool", the expression usually used for a person who speaks a foreign language well but fails to understand the cultural content of the language. Intercultural communicative competence includes the ability to communicate in a variety of contexts (Lázár, Huber-Kriegler, Lussier, Matei, \& Peck, 2007). There are many other descriptions of intercultural communication, but the definition used by the Council of Europe is precise: "the ability of a person to act in a foreign language in a linguistically, sociolinguistically and pragmatically appropriate way" (2001).

Mutual respect between different communities stems from learning each other's languages. An example is the German diaspora in Kyrgyzstan, which was one of the largest minorities in the country for 100 years. During their entire history in Kyrgyzstan, there has not been a single case of Germans clashing with any other ethnic or religious group. Mr. Anatoly König, who is the head of the German community in the mentioned country, shared the following story:

When people respect national, cultural and religious traditions, they live in peace and harmony. Therefore, we, Russians, Kyrgyz and Germans, have to think with our own heads. Then we will live in peace and harmony. Take the village of Internationalnoye. Only Germans used to live here. In the neighboring villages Bozbarmak and Jarbash, there were only Kyrgyz. When I was a kid, my father was a supplier. We used to go there and the Germans would speak Kyrgyz, and the Kyrgyz would speak German, because they lived in brigades, and the brigadier could be a Kyrgyz or a German (Mambetaliev, 2018, p. 17).

Mr. König is not a religious man, but says his father was a Lutheran and his mother was a Tatar, whereas now his wife is Russian and his children are Orthodox Christians.

\section{Competencies for sustainable communication in multilingual campuses}

A study has shown that one of the main pre-conditions for a peaceful coexistence of different ethnic and cultural groups is a non-biased knowledge about worldviews of each other (The European Commission, 2011). The best place to obtain such knowledge is an education setting where people also learn 
intercultural communication skills, which help individuals to develop cognitive, affective, and operational skills (Reed, 2008), deliver information in a way that changes attitudes from hostile into trust (Forgas, 2008, p. 133), and explain the rationale for developing aspirations essential for durable democracy (Welzel, 2006, p. 5-10). Such views are usually a result of quality education, which presents non-biased and holistic approaches to knowledge.

Diversity on campuses may have different effects on relations between students of diverse linguistic and cultural backgrounds. It may affect academic achievement of both majority- and minority-group students (Ewijk \& Sleegers, 2010). Ethnic minority students may feel better self-esteem in diverse classrooms (Juvonen, Nishina, \& Graham, 2006). According to Stahl, Maznevski, Voigt, \& Jonsen (2010), "[c]ulturally diverse groups generate more creative solutions. The European Union, as Hortobágyi (2008, p. 271) writes, is "faced with increasing importance of languages, which leads to economic development, improves employability and labor force mobility of employees, and promotes foreign trade". Furthermore, "in these instances, translation and interpreting techniques (required almost on a daily basis in authentic situations) definitely improve awareness of one's own mother tongue" (Hortobágyi, 2008, p. 272).

While living in multilingual campus students learn another language and gradually absorb elements of a new culture. Intercultural competency also should include empathy and respect toward "otherness" (Csepes, et al., 2015, p. 43). Without a desire to learn from people of different background, the skill, such as empathy and respect, will not develop (Vos, 2018, p. 12). At the same time, international students not only explore cultural variety and learn languages, but also understand themselves and their own linguistic aspects better. When they become aware of ethnic and cultural differences, they start examining their own cultures (Lázár, et al., 2007). However, longer accommodation to the new country may also accelerate alienation from the home country, and the person cannot decide any longer, where he/she feels at home (Navracsics, 2016). Returning home after several years, they find themselves somewhat different than their relatives, friends and other compatriots, while the environment sees him or her the same way. 
Faculty and administration members on multilingual campuses should be aware of the main aspects of being an educator in multilingual settings. Such awareness helps them to facilitate the differences, avoiding misunderstanding of the student's aptitudes and intentions: "when educators face these problems, the spirit of multiculturalism demands that everyone's commonality be recognized and affirmed" (Samovar et.al., 2009, p. 337). Furthermore, educators also should take into consideration the fact that each sociolinguistic group has its own approaches to learning, as Hofstede described, "our cognitive development is determined by the demands of the environment in which we grew up" (quoted from Csepes, et al., 2015, p. 148). The competences for multilingual education settings should have the ability to look upon oneself from different angles and act as a mediator (Csepes, et al., 2015, p. 59). Therefore, the education institution needs to develop language policies, which include socio- and psycholinguistic aspects of learning processes as well. This poses questions: what are the main barriers for developing positive relationships among students and educators from different sociolinguistic backgrounds and what are the main strategies to overcome the barriers? To answer these challenging research questions, the study employed a literature review of top authors in the field to present a summary of their answers to problems of communication in multiethnic/multilingual/multicultural education settings.

\section{Findings}

\section{The most common barriers for communication in multilingual communities}

Obstacles to building long-lasting relationships between students of different linguistic and cultural background include both verbal and non-verbal barriers, which may stem from both social and psychological issues. While vocabulary, syntax, idioms, slang and accents cause difficulties for communication, discrimination on the basis of racism, ethnocentrism, stereotyping, and prejudice hinder "coming together in a type of fanaticism that completely obstructs any form of successful intercultural communication" (Samovar et al., 2009, p. 175). In addition, psycholinguistic barriers, such as not paying 
full attention to what the other student is saying in the classroom, a lack of interest in the topic or issue that is being discussed, and differences in perception add to the problem, since "knowledge, skills, and attitudes comprise important components of intercultural competence" (Emert, 2008, p. 35). Moreover, cultural barriers which come from levels of context, value of time, negative stereotypes and prejudices as well as feelings and emotions (Farnen, 2017) also create problem zones in developing intercultural communication in multilingual education environment.

Bajzát (2016) describes the following situation, where communication problem may stem from languages which took different hierarchichal positions:

Intercultural communication involves speakers of different cultural backgrounds with different mother tongues; therefore, they can communicate by using the mother tongue of speaker $A$, or the mother tongue of speaker $B$, or they can choose a third language. In the first case, speaker $A$ is at an advantage over speaker $B$ both at linguistic and cultural levels; and speaker $B$ is at a disadvantage. In the second case, speaker B is at an advantage over speaker $A$. In the third case, both speakers have to face different linguistic and cultural differences and difficulties, because they "... bring their own sociocultural expectations of language to the encounter. Speakers' expectations shape the interpretation of meaning in a variety of ways" [4]. Due to these differences in language usage, communication may result in misunderstandings or even conflicts (p. 4).

As an African proverb goes, "Silence is also a speech". Nonverbal communication is present in every culture and covers the following topics: physical appearance (attire), proxemics (space and distance), chronemics (time), kinesics (facial expressions, movement and gestures), haptics (touch), oculesics (eye contact and gaze) and vocalics (paralanguage). It can be also expressed through body movement, posture, gestures (pointing, beckoning, acceptance and understanding, frequency and intensity of gestures), facial expressions (smile), eye contact and gaze or touch (Bajzát, 2016, p. 3; Samovar et al., 2009, p. 260-275). Misusing and misinterpretation of nonverbal communication may cause a confusion. The role of language policymakers and implementers is to introduce the students to at least major issues related to this important part of intercultural communication. 
Stereotypical and prejudicial expressions are one of the major problems in multilingual communities. Stereotypical expressions are the standardized ideas about groups of people that all have the same quality and they transmit this bias from generation to generation, from one geographical place to another. However, some authors classify stereotypical expressions as negative and positive. For example, saying that "Japanese are intelligent and well-mannered" would be a positive remark about Japanese people, which adds a positive stereotypical expression about Japanese people. In contrast, saying "Jews are scheming" would add a negative and false stereotypical expression about Jewish people. Both of these verbal expressions, however, contain an overgeneralization about two ethnic groups that narrow the listener's understanding about them. Therefore, stereotypical expressions, whether positive or negative, do not help to positive communication. Such stereotypes function as a "filter", as Samovar et al., pointed out, and "they only allow in information that is consistent with information already held by the individual" and thus "what might be the truth is never given a chance" (2009, p. 172). If one encounters with hostile looks in an unfamiliar community for no reason, he or she can resort to the stereotypical expression formed among the community about their country, ethnicity, race, etc.

Negative stereotypical expressions, however, sometimes may be true and usable for various purposes. For example, in his letter to a young community leader, Apostle Paul uses a negative stereotypical expression to discipline the community, when he writes, "[o]ne of the Cretans, a prophet of their own, said, 'Cretans are always liars, evil beasts, lazy gluttons.' This testimony is true. Therefore, rebuke them sharply, that they may be sound in the faith". (Titus, 1:12-16, Bible). Stereotypical judgements target a larger group of people, than the size of "the Cretan" community, and involves innocent individuals and people who suffer unjustly. In this letter, the lexicon of the Apostle contains very harsh vocabulary about the Cretans, but while the Cretan prophet probably had a negative stereotypical expression about his people, Paul uses it to discipline his students, whom he knew personally and maintained very close relationships.

Another barrier is prejudice, which involves "an evaluative dimension" (Samovar, Porter, \& McDaniel, 2009, p. 173). Prejudice may also function as ego-defensive, utilitarian and value-expressive knowledge and may express 
themselves through antilocution, withdrawing from contact, discrimination, physical attack and extermination. Racist expressions are another barrier, which an individual or a community may maintain. Racism is rooted in "culture, economics, psychology and history" (Samovar, Porter, \& McDaniel, 2009, p. 176). Popular dictionaries define racism as "prejudice, discrimination, or antagonism directed against someone of a different race based on the belief that one's own race is superior" (Oxford Dictionaries, 2019).

Ethnocentrism is the next widely spread concept all over the world. The same dictionary provides a general explanation of ethnocentrism as "Evaluation of other cultures according to preconceptions originating in the standards and customs of one's own culture" (Oxford Dictionaries, 2019). All humans are to some extent ethnocentric, falling somewhere on a scale between "low" and "high" ethnocentricity and "the more ethnocentric one's worldview, the less intercultural competent the individual" (Emert, 2008, p. 31). High or low levels of ethnocentricity influence an individual's ability for positive communication in multilingual education environments. Individuals with high ethnocentricity will experience the largest barriers with those who are different from them. Highly ethnocentric individuals may feel "suspicious, defensive, and hostile" toward international students, especially students who have different social and cultural norms from the in-group. However, ethnocentricity is not always negative. Those with low ethnocentricity may feel "curious, interested, and inspired" by their intercultural interactions and, as a result, experience the benefits of increased intercultural competence (Neuliep \& McGroskey, 1997). Given this, personal awareness of our own ethnocentricity and its effect on our ability to work with students suddenly becomes more important.

\section{The main strategies to overcome the barriers}

Exposing children to differing cultures during early education stage is a good strategy to mitigate hostile stereotypes: "Children who have face-to-face contacts with other groups have fewer negative stereotypes than those who are denied such contacts" (Samovar et al., 2009, p. 172-173). Distinguishing between different types of stereotyping and being open-minded is hepful to reduce the effect of steretypes. 
Expressions of prejudice may fade away gradually when people are in frequent contact with each other as positive contacts lower the level of prejudice (Samovar et al., 2009, p. 176). Another strategy for overcoming prejudice is education programs. For religious communities, the relevant expressions include, "judge not, that you be not judged" and further "for with the judgment you pronounce you will be judged, and with the measure you use it will be measured to you" (Bible, Matthew, 7:1-2). There are other similar insights: "do not judge by appearances" (John, 7:24) and "man looks on the outward appearance, but the Lord looks on the heart" (1 Samuel, 16:7). On the same issue, Samovar et al., (2009) suggest:

First, try to be honest with yourself when deciding if you hold some racist views. It is a simple point to state, but a difficult one to accomplish. Yet, confronting your racist views, if you hold any, is an important first step. Second, object to racist jokes and insults whenever you hear them. This daring and sometimes courageous act will send a message to other people that you denounce racism in whatever form it may take. Third, as straightforward as it sounds, we urge you to respect freedom... Fourth, examine the historical roots of racism (p. 178).

If one wants to grow up from ethnocentrism, he or she must "learn to be open to new views". The "lack of knowledge is a major cause of ethnocentrism". Therefore, being "alert to narrowness and intolerance in any form" will be helpful to move on from ethnocentrism towards global-mindedness. "Beware of the man of one book", said once St. Thomas Aquinas (Samovar, Porter, \& McDaniel, 2009, p. 182).

\section{Conclusions}

Multilingualism and multiculturalism are essential parts of modern campuses. This study has presented the most common barriers, which undermine positive relationships among students of different sociolinguistic backgrounds. It also described that learning each other's languages and cultures is a necessity. Without the skills described in this study, many advisers and students are prone to leave the dream to be learned members of the multilingual world. Therefore, equipping members of multilingual campuses with necessary and 
the most important strategies to overcome those barriers is of paramount importance today. Both international and local members of educational settings throughout the world are in need to deal effectively with many obstacles on their way to join the global community of leaders. Although those obstacles are as ancient as our world, there is still much for multilinguals to (re)learn and teach and to apply the strategies described in this paper.

\section{References}

Bajzát, T. (2016). The Most Common Barriers of Successful Intercultural Communication. International Multidisciplinary Scientific Conference. University of Miskolc. Retrieved from http://www.unimiskolc.hu/ microcad/publikaciok/2016/Gfeliratozva/G_4_Bajzat_Tunde.pdf

Council of Europe. (2018). Language Policy. Retrieved from Council of Europe: https://www.coe.int/en/web/language-policy/home

Csepes, I., Fekete, A., Kardos, E., Koczogh, H., Monos, K., \& Sanko, G. (2015). Challenges of the 21st century: an in-service teacher training course for EFL teachers. Debrecen: Debrecen University Press. Retrieved from http://tanarkepzes.unideb.hu/szaktarnet/kiadvanyok/challenges.pdf\# page $=39$

Emert, H. A. (2008). Developing Intercultural Competence through Teaching Abroad with Fulbright: Personal Experience and Professional Impact. Ann Arbor: Proquest LLC.

Farnen, K. (2017). Six Barriers to Intercultural Communication. Our Everyday Life. Retrieved from https://oureverydaylife.com/six-barriers-tointercultural-communication-12080535.html

Hortobágyi, I. (2008). Gateways to Successful Intercultural Communication. Bulletin of the Transilvania University of Braşov, 1(50), 271-272.

Lázár, I., Huber-Kriegler, M., Lussier, D., Matei, G., \& Peck, C. (2007). Developing and assessing intercultural communicative competence. A guide for language teachers and teacher educators. Graz, Austria: European Centre for Modern Languages/Council of Europe. Retrieved from

https://archive.ecml.at/mtp2/publications/B1_ICCinTE_E_internet.pdf 
Mambetaliev, A. (2018). Pluralism in Kyrgyzstan. Ottawa: Global Centre of Pluralism. Retrieved from https://www.pluralism.ca/pressrelease/history-of-pluralism-in-kyrgyzstan/

Matthews, P. (1994). Developing a language-in-education model. Amherst: University of Massachusetts at Amherst.

McKeiver, K. (2013). Identifying Barriers to Effective Intercultural Communication. NACADA: Academic Advising Today. Retrieved from https://www.nacada.ksu.edu/Resources/Academic-AdvisingToday/View-Articles/Identifying-Barriers-to-Effective-InterculturalCommunication.aspx

Navracsics, J. (2016). Living with two languages and cultures. The complexity of self-definition for bilingual individuals. Hungarian Journal of Applied Linguistics, 16(2), $13 . \quad$ Retrieved from http://alkalmazottnyelvtudomany.hu/en/home2/

Neuliep, J., \& McGroskey, J. (1997). The Development of Intercultural and Interethnic Communication Apprehension Scales. Jamescmccroskey. Retrieved from http://www.jamescmccroskey.com/ publications/169.pdf

Samovar, L., Porter, R., \& McDaniel, E. (2009). Communication between cultures (7 ed.). Boston: Wadsworth, Cengage Learning.

Vos, L. (2018). Teaching Intercultural Communicative Competence alongside Language Proficiency. Master's Thesis. Retrieved from https://dspace.library.uu.nl/handle/1874/360047 


\section{Askar Mambetaliev}

Panonijos universitetas, Vengrija; amambetaliev@alumni.umass.edu

\section{DARNIU SANTYKIU UNIVERSITETO MIESTELIUOSE BARJERAI IR STRATEGIJOS}

Santrauka. Straipsnyje aptariami komunikacijos aspektai daugiatautèse ir daugiakalbèse švietimo sistemose, darniu santykiu tarp studentu iš skirtingu kultūru pagrindiniai barjerai ir strategijos šiems barjerams iveikti. Pagrindiniai tyrimo klausimai: "Kokie yra pamatiniai darniu santykiu tarp studentu iš skirtingos etinès ir kalbinès aplinkos barjerai?" ir „Kaip iveikti šiuos barjerus?”. Šio straipsnio tikslas yra nustatyti ir ištirti svarbiausias problemas, kurios kenkia studentu tarpusavio supratimui ir bendradarbiavimui. Straipsnyje apžvelgiami tyrimai, atlikti garsiausiu šios srities specialistu. Apžvalgos tikslas yra pristatyti pagrindiniu santykiu problemu tarp studentu universiteto miesteliuose sprendimu santrauką. Straipsnis yra naudingas universitetu miesteliu vadovams, studentams ir mentoriams.

Pagrindinès sąvokos: komunikacija; santykiai; daugiakalbystė; barjerai; rasizmas; prietarai; stereotipai; strategijos. 